\title{
PREDICTING THE GROWTH CURVE OF BODY WEIGHT IN MALEO BIRDS (MACROCEPHALON MALEO)
}

\author{
Widya Pintaka Bayu Putra \\ Research Center for Biotechnology - Indonesian Institute of Science, Cibinong, Indonesia \\ Email: widya.putra.lipi@gmail.com
}

\begin{abstract}
Maleo bird (Macrocephalon maleo) is the one of protected bird's species and originated from Sulawesi island of Indonesia. This study was carried out to obtain the growth curve of body weight (BW) in mixed-sex Maleo birds from hatching to yearling ages. The growth curve in this study was calculated with non-linear regression of Logistic $(L)$ and Gompertz $(G)$ models using CurveExprt 1.4. computer program. The primary data in this study was cited from previous study through a literature study. Research showed that the asymptotic weight (A) in birds was $1825.34 \mathrm{~g}(\mathrm{~L})$ and $3429.23 \mathrm{~g}(\mathrm{G})$. The weight of inflection $\left(\mathrm{W}_{\mathrm{i}}\right)$ in studied birds were $912.67 \mathrm{~g}(\mathrm{~L})$ and $1260.75 \mathrm{~g}(\mathrm{G})$. The time of inflection $\left(\mathrm{t}_{\mathrm{i}}\right)$ in birds was 8.51 months (L) and 11.00 months $(\mathrm{G})$. The maximum growth rate in birds was $159.72 \mathrm{~g} / \mathrm{month}$ (L) and $151.29 \mathrm{~g} /$ month $(\mathrm{G})$. The coefficient of determination $\left(\mathrm{R}^{2}\right)$ in both models included of very high category $\left(0.80<\mathrm{R}^{2}<1.00\right)$ but the lower of standard error (SE) value showed in $\mathrm{L}$ model. It can be concluded that the non-linear regression of Logistic model can be used as BW predictors in mixed-sex Maleo birds.
\end{abstract}

Keywords: Body weight, growth curve, inflection, Maleo birds, non-linear regression

Received 14 January 2021 Accepted 23 July 2021

\section{INTRODUCTION}

Maleo birds (Macrocephalon maleo) are one of Indonesian endemic species that originated from Sulawesi island. According to the Rhodopsin (RDP1) nucleus gene, this bird was closed to other birds family of Aeypodius, Alectura, Talegalla and Leipoa [1]. The Maleo bird included of Since year 1931 IUCN (International Union Conservation of Nature and Natural Resources (IUCN) was recorded in the red data book [2]. In addition, CITES (Convention on International Trade in Endangered Species) was classified into Apendix I (endangered species). Therefore, since year 1970, the Maleo birds was decided as the one of protected animal in Indonesia through the decision of Ministry of Agriculture No: 421/Kpts/Um/8/1970 [3]. Moreover, since year 1990 the Maleo bird was decided as the mascot of Central Sulawesi province through the decision of Governor No: 184.44/1067/Ro/BKLH/1990 [4].

Unfortunately, the Maleo eggs hunting still occured in the many national park of Sulawesi for consumption purpose. Hence, the egg weight, egg length, egg width and egg index of Maleo birds were $211.70 \pm 12.32 \mathrm{~g} ; 10.18 \pm 0.35 \mathrm{~cm} ; 6.12 \pm 0.23 \mathrm{~cm}$ and $60.01 \pm 0.03$ [2]. Despite human, Maleo birds was threated by many predator animals of monitor lizard (Varatus salvator), wild boar (Sus celebensis), Phyton snake (Phyton reticulatus), Sail-fin lizard (Hydrosaurus amboinensis) and Sulawesi hawk-eagle (Spizaetus lanceolatus) [5].

Recently, the Maleo conservation center was established in many national park of Sulawesi. Hence, study in the growth characteristic of Maleo birds is important to obtain the suitable farming management system. Growth is a continous function during the animal's life from embryonic stages up to adult age and its mathematically explained by growth curve 
models. Growth curve for poultry generally have the characteristics: an accelerating phase of growth from hatching, a point of inflection in the growth curve at which the growth rate is maximum, a phase where growth rate is decelerating and a limiting value (asymptote) mature weight [6]. In addition, the growth curve are to describe the regular change generated by the live weight or some part of the animal with the age increasing, which commonly is a S-shaped (sigmoid) curve [7].

Two non-linear regression of Logistic (L) and Gompertz (G) models were widely used to predict the growth curve in birds with explain of point inflection about $50 \%$ (L) and $30 \%$ (G) from the asymptotic weight [8]. Unfortunately, study in growth curve analysis in Maleo birds was not reported. This study was aimed to predict the growth curve model of body weight in Maleo birds with $\mathrm{L}$ and $\mathrm{G}$ models using primary data from previous studies. The results in this study can be used as the basic information to evaluate the management system in Maleo conservation center.

\section{MATERIALS AND METHODS}

This research was conducted with the primary data of body weight (BW) in Maleo birds (Figure 1) from previous studies as presented in Table 1. However, the scope study in cited references were different compared to the present study. Two non-linear regression of Logistic (L) and Gompertz (G) models were used in this study to compute the growth curve of body weight using CurveExpert 1.4. computer program [9]. Hence, the mathematical formula in $\mathrm{L}$ and $\mathrm{G}$ as follow [10] :

Logistic : $\mathrm{W}_{\mathrm{t}}=\frac{\mathrm{A}}{1+\mathrm{Be}^{-\mathrm{kt}}} \quad \mathrm{W}_{\mathrm{i}}=\mathrm{A} / 2 \quad \mathrm{t}_{\mathrm{i}}=(\mathrm{Ln} . \mathrm{B}) / \mathrm{k} \quad \mathrm{MGR}=\left(\mathrm{W}_{\mathrm{i}} \times \mathrm{k}\right) / 2$

Gompertz: $\mathrm{W}_{\mathrm{t}}=\mathrm{Ae}^{-\mathrm{e}^{\mathrm{B}-\mathrm{kt}}} \quad \mathrm{W}_{\mathrm{i}}=\mathrm{A} / \mathrm{e} \quad \mathrm{t}_{\mathrm{i}}=\mathrm{B} / \mathrm{k} \quad \mathrm{MGR}=\mathrm{W}_{\mathrm{i}} \times \mathrm{k}$

where, $\mathrm{A}$ is the asymptotic (final) weight $(\mathrm{g})$; $\mathrm{B}$ is the scaling parameters (constant of integration); $\mathrm{k}$ is the maturing rate $(\mathrm{g} /$ month); $\mathrm{e}$ is the natural constanta $(2.72) ; \mathrm{t}$ is the time (month).

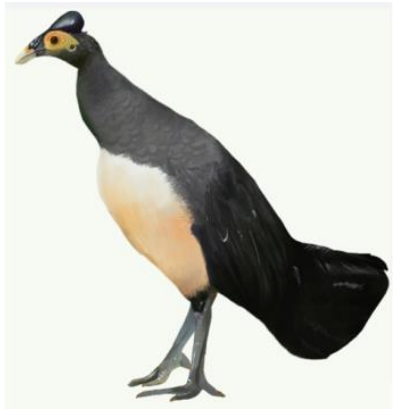

Figure 1. A Maleo bird (Macrocephalon maleo)

Table 1. Means $( \pm \mathrm{SD})$ of body weight in mixed-sex Maleo birds at different age

\begin{tabular}{ccccc}
\hline Age (month) & N & BW $(\mathrm{g})$ & Origin & Reference \\
\hline 0 & 10 & $126.0 \pm 30.9$ & & \\
1 & 10 & $148.5 \pm 20.1$ & Dumoga District, North Sulawesi & {$[11]$} \\
2 & 10 & $190.0 \pm 13.4$ & & \\
\hline 6 & 20 & $487.1 \pm 34.9$ & & \\
7 & 20 & $684.1 \pm 36.6$ & & \\
8 & 20 & $843.7 \pm 35.8$ & & \\
9 & 20 & $1001.6 \pm 39.5$ & Batui District, Central Sulawesi & {$[12]$} \\
10 & 20 & $1215.6 \pm 53.3$ & & \\
11 & 20 & $1341.7 \pm 35.2$ & & \\
12 & 20 & $1373.1 \pm 30.2$ & & \\
\hline
\end{tabular}


Therefore, the growth curve with high coefficient of correlation $\left(\mathrm{R}^{2}\right)$ and mean squared error (MSE) values can be suggested that this curve is accurate for BW prediction from hatching to yearling ages. In addition, both parameters were computed with a similar computer program.

\section{RESULTS AND DISCUSSION}

The asymptote weight (A) in Maleo birds was $1825.34 \mathrm{~g}(\mathrm{~L})$ and $3429.23 \mathrm{~g}(\mathrm{G})$ as presented in Table 2. According to the previous studies, the A value in Maleo birds with $\mathrm{L}$ model was closed to Italian Padovana Argentata/IPA cocks (1859 g) and Italian Padovana Camosciata/IPC $\times$ Italian Berlanda $(1957 \mathrm{~g})$ hens with similar model [13]. Meanwhile, the A value in Maleo birds with $\mathrm{G}$ model was closed to Broiler Line 1 chickens i.e. $3911.4 \mathrm{~g}$ (male) and $3618.10 \mathrm{~g}$ (female) with similar model [14]. The $\mathrm{W}_{\mathrm{i}}$ value in Maleo birds was $912.67 \mathrm{~g}$ (L) and $1260.75 \mathrm{~g}(\mathrm{G})$ as presented in Table 2. The $\mathrm{W}_{\mathrm{i}}$ value in Maleo birds with $\mathrm{L}$ model was closed to IPA (930 g), IPC (1061 g), Chinese Jinghai Yellow (1098.99 g) and Broiler (1093 g) $[13,15,16]$. Meanwhile, the $\mathrm{W}_{\mathrm{i}}$ value in Maleo birds with $\mathrm{G}$ model was closed to Broiler Line 1 (1330.18/1438.01 g), Broiler Line 2 (1253.57/1416.95 g) and Hubbard Broiler (1345/1605 g) chickens $[13,17]$. The $t_{i}$ value in Maleo birds was 8.51 months (L) and 11 months $(\mathrm{G})$ as presented in Table 2. The $t_{i}$ value in Maleo birds was higher than in chickens. Commonly, the sex maturity was occured in the inflection point. Hence, the breeding in Maleo birds can be assessed at about 8 to 11 months of age. Maleo included of monogamy birds that first egg production reached at 20 to 24 months with egg incubation along 53-63 days [18]. So, reproductive period of the Maleo birds was long and rarely in their nature wild. In addition, increasing the conservation center for Maleo birds and civil education to protect Maleo are important for keeping this birds from extinction. Despite, the coefficient of determination $\left(\mathrm{R}^{2}\right)$ in both models were about 0.99 (very high). Nevertheless, the lower means squared error (MSE) was observed in L model. In the future, study to determine the growth curve model with sex factor is important for obtaining the results accurately. The sex of Maleo birds can be identified based on their macrocephalon size and cloaca morphology [19].

Table 2. The growth parameters in Logistic and Gompertz models for body weight in mixed-sex Maleo birds

\begin{tabular}{lrrrrrrrr}
\hline \multicolumn{1}{c}{ Model } & $\mathrm{A}$ & \multicolumn{1}{c}{$\mathrm{B}$} & $\mathrm{k}$ & \multicolumn{1}{c}{$\mathrm{W}_{\mathrm{i}}$} & \multicolumn{1}{c}{$\mathrm{t}_{\mathrm{i}}$} & \multicolumn{1}{c}{$\mathrm{MGR}$} & $\mathrm{R}^{2}$ & MSE \\
\hline Logistic & 1825.34 & 19.69 & 0.35 & 912.67 & 8.51 & 159.72 & 0.997 & 42.74 \\
Gompertz & 3429.23 & 1.32 & 0.12 & 1260.75 & 11.00 & 151.29 & 0.995 & 57.67
\end{tabular}

A: asymptotic weight (g) when time goes to infinity; B: scaling parameters (constant of integration); $\mathrm{k}$ : maturing rate $(\mathrm{g} / \mathrm{week})$; $\mathrm{W}_{\mathrm{i}}$ : weight of inflection $(\mathrm{g})$; $\mathrm{t}_{\mathrm{i}}$ : time of inflection (months); MGR: maximum growth rate $(\mathrm{g}) ; \mathrm{R}^{2}$ : coefficient of correlation; MSE: means of squared error
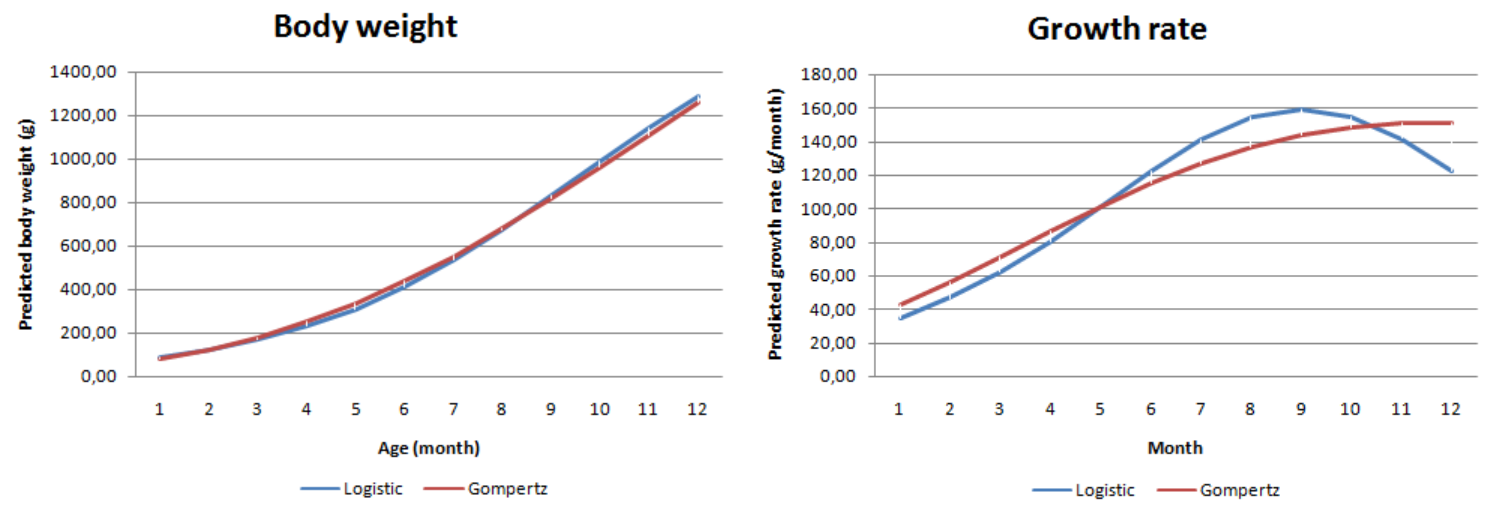

Figure 2. The growth curve (left) and growth rate (right) of mixed-sex Maleo birds based on non-linear regression of Logistic and Gompertz models 


\section{CONCLUSION}

The asymptotic weight in mixed-sex Maleo birds was 1825.34-3429.23 g with inflection of weight and time were about 912.67-1260.75 $\mathrm{g}$ and 8.50-11 months respectively. Thus, the L model was more accurate to describe the growth of Maleo birds rather than $G$ model.

\section{REFERENCES}

[1] I.M. Budiarsa, I.W.T. Artama, L. Sembiring, J. Situmorang, Phylogenetic analysis of the Maleo (Macrocephalon maleo) based on the first exon of Rhodopsin (RD1) nuclear gene sequences. Biota. 15 (2010) 160-166.

[2] I.G.N.P. Widnyana, Kajian morfologi dan morfometri telur burung Maleo (Macrocephalon maleo SAL. Muller 1846), J. AgroPet. 14 (2017) 31-37.

[3] H. Gunawan, Strategi burung Maleo (Macrocephalon maleo Sal. Muller 1846). Tesis (2000), Institute Pertanian Bogor, Bogor.

[4] M. Tanari, Y. Rusiyantono, Hafsah, Hatching technology of Maleo bird eggs (Macrocephalon maleo Sal. Muller 1846) as a conservation effort, J. Agroland. 15 (2008) 336-342.

[5] H. Gunawan, Food preference and consumption of Maleo Macrocehalon maleo Sal. Muller chick in weaning period, JPHKA, 1 (2004) 58-65.

[6] H.A. Fitzhugh, Analysis of growth curves and strategies for altering their shape, J. Anim. Sci., 42 (1976) 1036-1051.

[7] I.E. Arsoy, M. Mendes, S. Aktan, Growth curve establishment for American Bronze turkeys, Arch. Tierz., 49 (2006) 293-299.

[8] R.E. Ricklefs, Pattern of growth in birds, Ibis, 110 (1968) 419-451.

[9] D.G. Hyams, CurveExpert Basic, Release 1.4., https://docplayer.net/32911496Curveexpert-basic-release-1-4-daniel-g-hyams.html, 2010 (accessed 13 january 2021)

[10] M. Selvaggi, V. Laudadio, C. Dario, V. Tufarelli, Modelling growth curves in a nondescript Italian chicken breed: an oppurtunity to improve genetic and feeding strategies, J. Poult. Sci., 52 (2015) 288-294.

[11] A. Sumangando, Biologi perkembangan burung Maleo (Macrocephalon maleo, Sal. Muller 1846) yang ditetaskan secara ex-situ. Tesis (2002). Institut Pertanian Bogor. Bogor.

[12] M. Ali, Pertumbuhan Maleo (Macrocephalon maleo) umur 7 - 12 bulan dalam kandang penangkaran ek-situ PT. Panca Amara Utama, Kecamatan Batui, Kabupaten Banggai. Skripsi (2019). Universitas Tadulako, Manado.

[13] C. Rizzi, B. Contiero, M. Cassandro, Growth patterns of Italian local chickens population, Poult. Sci., 92 (2013) 2226-2235.

[14] H. Atil, M. Grossman, C. Takma, Comparison of growth curve models on average and individual body weights in chickens, Arch. Geflugelk., 71 (2007) 1-5.

[15] Y. Yang, D.M. Mekki, S.J. Lv, L.Y. Wang, J.H. Yu, J.Y. Wang, Analysis of fitting growth models in Jinghai mixed-sex Yellow chicken, Int. J. Poult. Sci., 5 (2006) 517 521.

[16] Al-samarai, F.R., Growth curve of commercial Broiler as predicted by different nonlinear functions, American J. Appl. Sci. Res., 1 (2015) 6-9.

[17] H. Eleroğlu, A. Yıldırım, A. Şekeroğlu, F.N. Çoksöyler, M. Duman, Comparison of growth curves by growth models in slow-growing chicken genotypes raised the organic system, Int. J. Agric. Biol., 16 (2014) 529-535.

[18] Y. Rusiyantono, M. Tanari, M.I. Mumu, Consrvation of Maleo bird (Macrocephalon maleo) through egg hatching modification and ex situ management, Biodiversitas, 12 (2011) 171-176. 
[19] I.G.N.P. Widnyana, B. Sundu, Rusdin, M. Tanari, Sex detection in Maleo bird (Macrocephalon maleo Sal. Muller 1846) nurtured in ex-situ conservation through body morphological and hormonal studies, Int. J. Vet. Sci. Agric. Res., 1 (2019) 17-22. 